\title{
ALKALINE PHOSPHATASE IN PRE-DECIDUAL CELLS OF THE HUMAN ENDOMETRIUM
}

\author{
E. W. WILSON \\ University of Sheffeld, Department of Obstetrics and Gynaecology, \\ Fessop Hospital for Women, Sheffeld, S3 7RE
}

(Received 4th March 1969)

During the menstrual cycle, the human endometrium shows alterations in the activity of alkaline phosphatase in respect of both localization and amount. The changes in enzyme activity in the epithelial cells of the glands, and in the endothelium of blood vessels, have been consistently demonstrated histochemically (Atkinson \& Engle, 1947; McKay, Hertig, Bardawil \& Velardo, 1956) and are well known. Enzyme activity in the stromal cells of the endometrium is denied by all published work except that of Mookerjea (1961), who described a peak of alkaline phosphatase activity in these cells at the end of the follicular phase of the cycle. Because most studies of alkaline phosphatase in the endometrium have used tissue fixation, which is known to destroy much of the enzyme, it was decided to examine fresh tissue for alkaline phosphatase activity.

Endometrium was obtained by curettage from sixty-four women at varying stages in the menstrual cycle, and was immediately frozen in thick-walled glass tubes kept in equilibrium with solid carbon dioxide. The tissue was sectioned at $10 \mu$ in a cryostat with the chamber temperature between $-25^{\circ} \mathrm{C}$ and $-35^{\circ} \mathrm{C}$ and with the knife cooled to about $-60^{\circ} \mathrm{C}$. Sections mounted on warm slides were stained by a modified Gomori method (Pearse, 1960) without fixation, the incubation time being $1 \mathrm{hr}$ at $37^{\circ} \mathrm{C}$, and then mounted in glycerine jelly. Histological examination of all specimens showed a normal appearance for the cycle date.

The findings in the endometrial gland cells and in the blood vessels were similar in every way to the description given by McKay et al. (1956) and will not be discussed further.

Alkaline phosphatase activity was absent from stromal cells in specimens obtained before Day 23 of the menstrual cycle. In the twelve specimens dating from Days 23 to 27, enzyme activity was demonstrated in stromal cells surrounding spiral arterioles (Pl. 1, Fig. 1). The enzyme appeared to be localized to the cell nuclei when preparations were examined by phase-contrast microscopy. Alkaline phosphatase was observed in those cells which are involved in the pre-decidual reaction seen in the endometrium during the latter part of the luteal phase (Pl. 1, Fig. 2). The reaction was not intense and may only have been demonstrable because unfixed tissue was used. This may explain the absence of a positive reaction in these cells reported by other workers studying this tissue. 
Pritchard (1947), in a study of the pregnant rat uterus, found that the decidual cells showed intense alkaline phosphatase activity in the nuclei from Days 5 to 8 and that thereafter enzyme activity diminished until only some decidual cells showed cytoplasmic enzyme. Finn \& Hinchliffe (1964) demonstrated a similar enzyme pattern in the pregnant mouse uterus, and in the pseudopregnant mouse uterus when deciduoma formation was stimulated. Moog (1944) found that differentiating cells in the chick embryo showed alkaline phosphatase activity in the nuclei while those functioning cells which showed any enzyme activity showed it in the cytoplasm. It appears, therefore, that human decidual cells undergo similar changes to decidual cells in rodents, the only difference being that a conceptus, or mechanical stimulus, is not necessary for initiation of the process in humans. There is little information about alkaline phosphatase in human pregnancy decidua, although Wislocki (1951) described traces of enzyme in cells of the decidua basalis at the end of pregnancy. One difficulty is that decidua from very early pregnancies, just after implantation, is available only by chance. The full development of the human decidual alkaline phosphatase reaction may not, therefore, be known for some time. A way around this is suggested by the development of organ culture methods, and if the appropriate amounts of oestrogen and progesterone could be maintained in such a culture some important information might be gained. The findings in the present study also suggest an additional method of assessing the functional adequacy of endometrium in patients with infertility.

\section{REFERENCES}

Atkinson, W. B. \& Engle, E. T. (1947) Studies on endometrial alkaline phosphatase during the human menstrual cycle and in the hormone treated monkey. Endocrinology, 40, 327.

Finn, G. A. \& Hinchliffe, J. R. (1964) Reaction of the mouse uterus during implantation and deciduoma formation as demonstrated by changes in the distribution of alkaline phosphatase. 7. Reprod. Fert. 8, 331.

McKay, D. G., Hertig, A. T., Bardawil, W. A. \& Velardo, J. T. (1956) Histochemical observations on the endometrium. Obstet. Gynec., N.Y. 8, 22.

Moog, F. (1944) Localizations of alkaline and acid phosphatases in the early embryogenesis of the chick. Biol. Bull. mar. biol. Lab., Woods Hole, 86, 51 .

MookerjeA, G. (1961) Cytochemical patterns of the normal and abnormal endometrium. Nucleus, Calcutta, 4, 81 .

PeARSe, A. G. E. (1960) Histochemistry, theoretical and applied. Churchill, London.

Pritchard, J. J. (1947) The distribution of alkaline phosphatase in the pregnant uterus of the rat. 7. Anat., Lond. 81, 352.

WisLocki, G. B. (1951) The histology and cytochemistry of the basal plate and septa placentae of the normal human placenta delivered at full term. Anat. Rec. 109, 359. 
PLATE 1

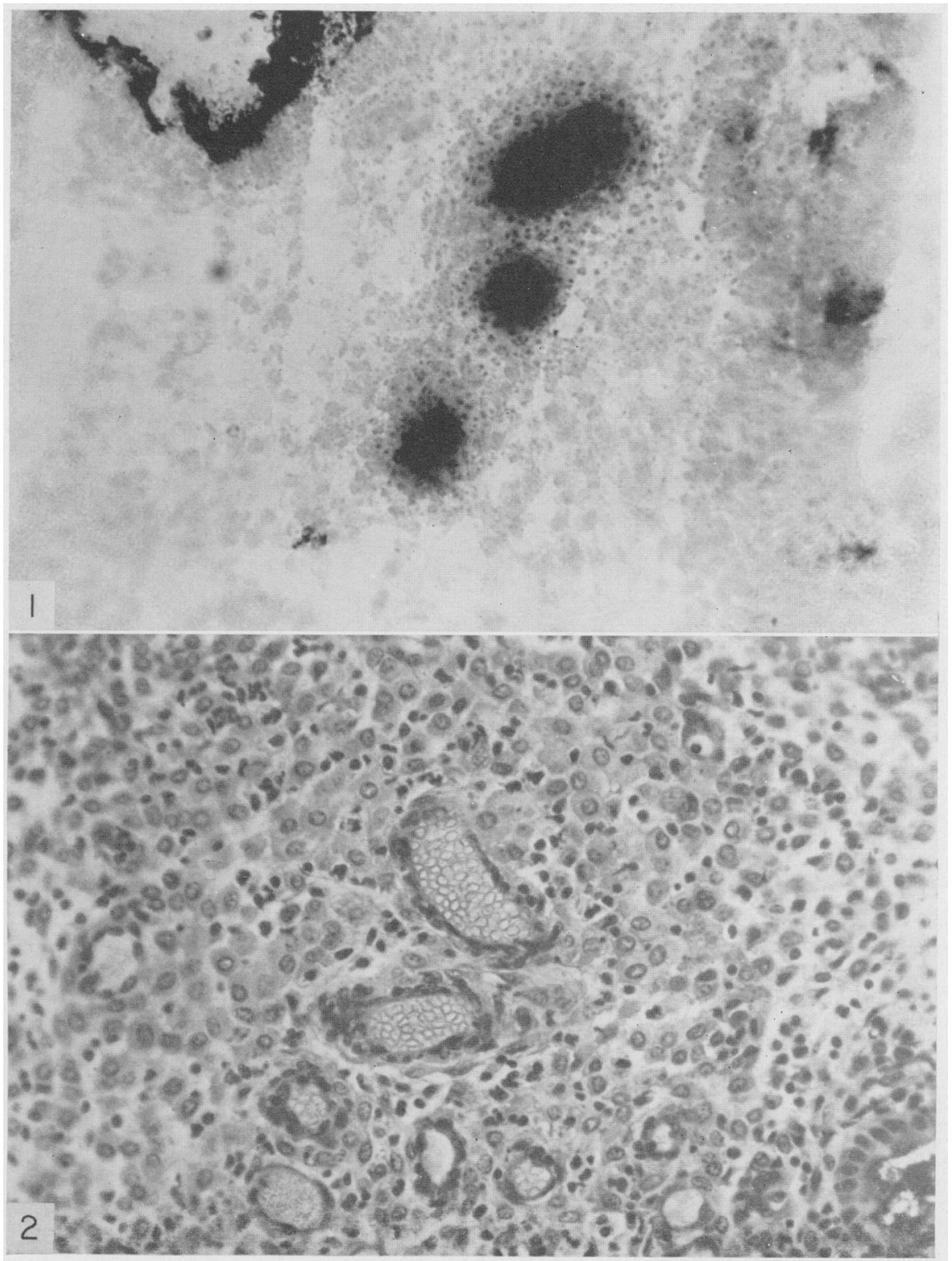

FIG. 1. Human endometrium, Day 24, stained for alkaline phosphatase by the calciumcobalt method of Gomori. Pre-decidual cells surrounding arterioles show a positive reaction. $\times 340$.

FIG. 2. Human cndometrium, Day 24, haematoxylin and eosin staining. Pre-decidual cells surround the spiral arterioles, $\times 340$. 